\title{
CLUSTER MODEL OF THE CHILDREN'S TOURISM AND RECREATION TERRITORIAL COMPLEX IN UKRAINE
}

\author{
Kateryna DOLHOVA \\ Taras Shevchenko National University of Kyiv, Ukraine \\ kate.dolhova@gmail.com
}

\begin{abstract}
Human geography studies on children's tourism and recreation comprise a powerful tool contributing to bold theoretical foundation for the development of children's tourism and recreation in Ukraine. The purpose of this paper is to develop a cluster model of the children's tourism and recreation territorial complex in Ukraine. The main goal of this study is achieved by virtue of the review of human geography literature and the use of cluster approach. As a result, this article generalizes the basic forms of geospatial organization of society and economy being in focus of human geography, describes the children's tourism and recreation territorial complex as an object of human geography, and reveals the cluster structure of the children's tourism and recreation territorial complex. The paper presents the definitions of "children's tourism and recreation cluster" and "children's tourism and recreation territorial complex", as well as suggests the cluster model of children's tourism and recreation territorial complex. These theoretical developments will improve on children's tourism and recreation studies in the field of human geography.

Key words: human geography, children's tourism and recreation, territorial complex of recreation, children's tourism and recreation territorial complex, children's tourism and recreation cluster, cluster structure of children's tourism and recreation territorial complex.
\end{abstract}

DOI: https://doi.org/10.17721/2413-7154/2017.78.47-52

UDC: $911.3: 316+338.48+379.8$

\section{КЛАСТЕРНА МОДЕЛЬ ТЕРИТОРІАЛЬНОГО КОМПЛЕКСУ ДИТЯЧОГО ТУРИЗМУ ТА РЕКРЕАЦІї В УКРАЇНІ}

\author{
Катерина дОЛгОВА \\ Київський начіональний університет імені Тараса Шевченка \\ kate.dolhova@gmail.com
}

\begin{abstract}
Анотація: Суспільно-географічні дослідження дитячого туризму та рекреації дозволяють сформувати потужне теоретичне підґрунтя для здійснення відповідної туристсько-рекреаційної діяльності в Україні. Метою даного дослідження було розробити кластерну модель територіального комплексу дитячого туризму та рекреації в Україні. Для досягненя поставленої мети було використано літературний аналіз публікацій суспільногеографічної тематики та застосовано кластерний підхід. В результаті узагальнено уявлення про основні форми геопросторової організації суспільства, господарства, які можуть виступати об'єктом суспільно-географічних досліджень, охарактеризовано територіальний комплекс дитячого туризму та рекреації як об'єкт суспільногеографічних досліджень, відображено кластерну структуру територіального комплексу дитячого туризму та рекреації в Україні. Запропоновано визначення поняття «кластер дитячого туризму та рекреації», «територіальний комплекс дитячого туризму та рекреації», а також кластерну модель територіального комплексу дитячого туризму та рекреації в Україні. Такі науково-теоретичні розробки дозволять вдосконалити практику вивчення дитячого туризму та рекреації з точки зору суспільної географії.

Ключові слова: суспільно-географічні дослідження, дитячий туризм та рекреація, територіальний рекреаційний комплекс, територіальний комплекс дитячого туризму та рекреації, кластер дитячого туризму та рекреації, кластерна структура територіального комплексу дитячого туризму та рекреації.
\end{abstract}

DOI: https://doi.org/10.17721/2413-7154/2017.78.47-52

UDC: $911.3: 316+338.48+379.8$

Постановка проблеми. Дитячий туризм та рекреація виступає однією 3 форм туристськорекреаційної діяльності, яка пов'язана з організацією відпочинку, оздоровлення, проведення дозвілля підростаючого покоління. Практика здійснення такої туристсько-рекреаційної діяльності в Україні та світі говорить про формування відповідної

(C) К. Долгова складової сфери послуг, яка орієнтована на задоволення потреб дитячого населення. Наша держава має потужний ресурсний та соціальноекономічний потенціал для розвитку дитячого туризму та рекреації, який, на жаль, повністю не використовується. Однією 3 причин такого неефективного використання сприятливих умов та ресурсів $\epsilon$ відсутність грунтовних наукових розробок для потреб дитячого туризму та рекреації. 
Відбувається безсистемне вивчення такого явища та фрагментарне висвітлення окремих проблем в наукових публікаціях. Крім того, відсутній єдиний підхід до визначення самого поняття «дитячий туризм», «дитяча рекреація», «дитячий туризм та рекреація».

В той же час, конкретні результати суспільногеографічних досліджень проблеми дитячого туризму та рекреації можуть сформувати потужне теоретичне підгрунтя для здійснення такого виду туристько-рекреаційної діяльності в Україні. Так, за допомогою суспільно-географічної методології можна, в першу чергу, обгрунтувати єдиний підхід до визначення об’єкта суспільно-географічного дослідження дитячого туризму та рекреації, а також його сутності та основних ознак. Крім того, вивчення актуального сьогодні питання територіальної організації дитячого туризму та рекреації в Україні, повинно базуватися на обгрунтуванні можливих форм такої організації для потреб дитячого туризму та рекреації.

Аналіз останніх досліджень і публікацій. Серед наукових публікацій 3 суспільно-географічної тематики можна знайти низку праць, які розкривають сутність тої чи іншої форми геопросторової організації суспільства, господарства як об’єкта суспільно-географічних досліджень. Існують також роботи, які присвячені «рекреаційному комплексу» (О.Г.Топчієв) [15], «територіальному рекреаційному комплексу» (Є.А. Котляров) [7], «територіально-рекреаційній системі» (В.І.Стафійчук, В.К. Свдокименко, I. В. Смаль, М.В.Крачило, О.О.Любіцева та ін.) $[11$, с. $15 ; 14$, с. 30], туристському кластеру (Алєксандрова А.Ю.) [1] як об'єкту суспільногеографічних досліджень. У літературі фактично залишається не розкритим питання «територіального комплексу дитячого туризму та рекреації», однак серед вітчизняних науковців існує думка про те, що дитячий туризм слід розглядати як «територіальну рекреаційну систему» (Колотуха О. В.) [6, с. 6]. При цьому, методологічною проблемою при дослідженні туристськорекреаційної діяльності виступає і1і структурування, систематика та класифікація за функціональними видами i просторовими масштабами [9, с.562].

Мета дослідження - розробити кластерну модель територіального комплексу дитячого туризму та рекреації в Україні.

Виклад основного матеріалу. Літературний аналіз публікацій зі суспільно-географічної тематики допоміг узагальнити уявлення про основні форми геопросторової організації, які можуть виступати об'єктом суспільно-географічних досліджень, а також охарактеризувати як такий об'єкт територіальний комплекс дитячого туризму та рекреації. Також був застосований кластерний підхід для зображення функціональної структури територіального комплексу дитячого туризму та рекреації в Україні, як результат - запропоновано його кластерну модель.
Об'єктом суспільно-географічних досліджень, в широкому розумінні, виступає вся ландшафтна оболонка Землі. На думку Топчієва О. Г., «об'єкти суспільно-географічних досліджень повинні деталізуватися i бути більш конкретними» в залежності від мети та завдань такого дослідження [15, с. 73]. Так, об'єктом суспільно-географічних досліджень може бути цілісний комплекс компонентів ландшафтноїоболонки, якийназиваютьгеографічним комплексом, територіальним соціально-економічним комплексом, суспільно-географічним комплексом $[13$, с. $207 ; 15$, с. 73$]$.

Суспільно-географічний комплекс «виокремлена на основі суспільно-географічних зв'язків територіальна i комплексно-пропорційна структура матеріально-речовинних i духовних компонентів діяльності людини» (за Пістуном М.Д.) [9, с. 33]. Суспільно-географічний комплекс включає наступні компоненти: територію, населення, матеріальне виробництво, невиробничу сферу та інфраструктуру. Обов'язковою умовою для існування такого комплексу є цілісність та взаємодія його компонентів, яка забезпечується відповідними зв'язками [9, с. 33].

Топчієв О.Г. наголошує на тому, що «рекреаційна діяльність поєднує різноманітні види відпочинку i значну сукупність допоміжних і обслуговуючих видів діяльності, які разом називають рекреаційним господарством або рекреаційним комплексом» [15, c. 62]. Вчений вважає, що «рекреаційне господарство являє собою типовий міжгалузевий комплекс, оскільки у рекреаційному обслуговуванні прямо чи опосередковано приймає участь багато різних галузей економічної діяльності» [15, с. 562].

Рекреаційний комплекс - це «сукупність галузей i видів економічної діяльності, які забезпечують рекреаційними послугами населення країни, регіону, міста та створюють необхідні передумови для нормального функціонування туристично-рекреаційного підприємства» (за Топчієвим О.Г.) [15, с. 562].

Розвиток туристсько-рекреаційного комплексу відбувається на певній території, що дозволяє визначати такий комплекс як територіальний.

Територіальний рекреаційний комплекс являє собою поєднання рекреаційних установ і відповідних підприємств інфраструктури, об'єднаних тісними виробничими i економічними зв'язками, а також спільним використанням географічного положення, природних і економічних ресурсів території, яку займає комплекс (за Котляровим Є.В.) [7, с. 4].

Територіальний рекреаційний комплекс - особлива форма територіальної організації господарства, яка формується в процесі взаємопов'язаного розвитку рекреаційної та інших видів господарської діяльності на компактній території, що має специфічні соціально-економічні і природні характеристики (за Бейдиком О.О.) [2].

Оскільки туристсько-рекреаційна діяльність - різновид суспільної діяльності людини, а територіальному комплексу притаманні вищезазначені риси 
суспільно-географічного комплексу, то можна говорити про територіальний туристськорекреаційний комплекс як про об'єкт суспільногеографічних досліджень.

Відповідно до концепції Котлярова Є.В. про рекреаційні комплекси виділяють (за функціональним призначенням або спеціалізацією рекреаційних підприємств на основі профілюючих галузей рекреаційного господарства та за стадіями формування комплексу) такі типи рекреаційних комплексів: 1) санаторно-курортний; 2) туристсько-оздоровчий; 3) санаторно-туристсько-оздоровчий; 4) мисливсько-риболовний; 5 ) туристсько-оздоровчо-мисливсько-риболовний; 6) всеохоплюючий [7, с. 12]. Кожен 3 таких рекреаційних комплексів включає розвиток відповідних видів рекреаційної діяльності та підприємств обслуговування [7, с. 13].

Топчієв О.Г., розглядаючи функціональну структуру рекреаційного комплексу, також виділяє типи таких комплексів, які відповідають рекреаційним підкомплексам в розробленій ним схемі, а саме: 1) курортно-оздоровчий; 2) пізнавально-діловий; 3) спортивний; 4) екологічний; 5) релігійний; 6) розважальний та ін. Науковець розглядає рекреаційне господарство як міжгалузевий комплекс, який за своєю функціональною структурою охоплює різноманітні рекреаційні цикли 3 надання рекреаційного обслуговування та комплексу супутніх послуг, сукупність яких відповідає рекреаційному кластеру [15, с. 563].

Дослідник наголошує на тому, що саме такі кластери визначають ту чи іншу спеціалізацію рекреаційних підприємств, той чи інший рекреаційно-туристський профіль. Кластери рекреаційних послуг відповідають видам рекреаційної діяльності, наприклад, курортнолікувальний, курортно-оздоровчий, спортивнооздоровчий відпочинок, пізнавальний, історикоетнографічний, історико-культурний, науковий, діловий, торговий, спортивний, ландшафтноекологічний, релігійний; гостьовий і родинний, розважальний туризм. Рекреаційні заклади 3 однаковими кластерами рекреаційних послуг мають однотипову спеціалізацію і займаються однаковими видами рекреаційної діяльності, тому функціонально їх можна об’єднати у відповідні підкомплекси [15, с. 564-565].

Тобто функціональнаструктура рекреаційного комплексу, окрім рекреаційних циклів та кластерів, які виступають первинними ланками рекреаційної діяльності, включає рекреаційні підкомплекси, які було зазначено вище.

На думку Л. Корецького та І.Смаля, найважливішими елементами територіального рекреаційного комплексу $\epsilon$ туристський, санаторно-курортний, оздоровчо-рекреаційний, культурно-рекреаційний підкомплекси [14, с. 34].

Котляров Є.В. вважає, що існують дві групи передумов, які зумовлюють формування територіального рекреаційного комплексу: природні та соціально-економічні умови [7, с. 5-6]. Такі умови науковець розділяє на відповідні групи: базисноресурсні, просторово-економічні та соціальноекономічні [7, с.7]. Науковцем охарактеризовано такі етапи розвитку територіальних рекреаційних комплексів: 1) просте агломерування різно-

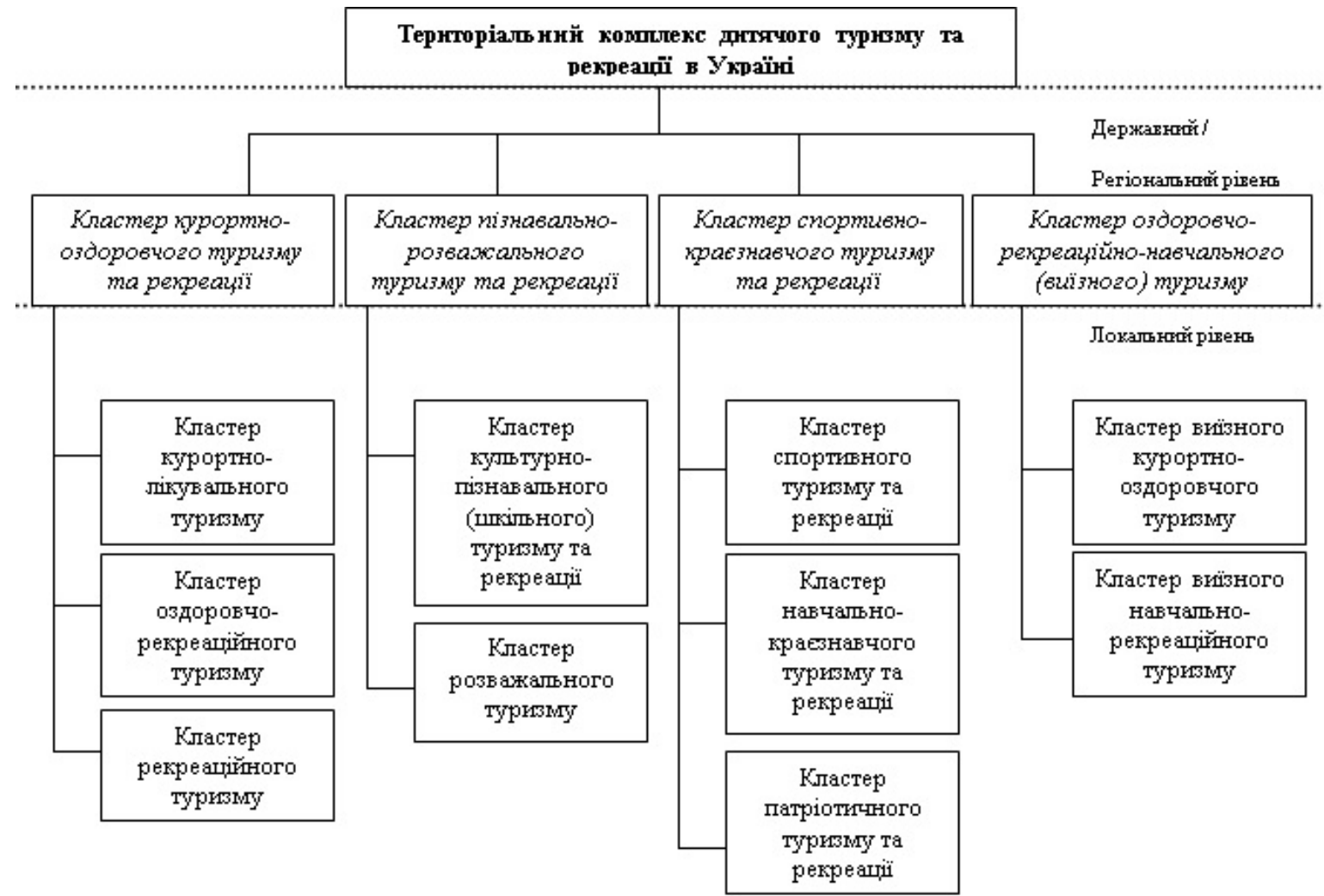

Рис. 1. Кластерна модель територіального комплексу дитячого туризму та рекреації в Україні (авторська розробка) 
Таблиия 1.

Характеристика кластерів комплексу дитячого туризму та рекреації на локальному територіальному рівні в Україні (авторська розробка)

\begin{tabular}{|c|c|c|}
\hline Кластер & Ядро кластера & Послуги, які надають підприсмства кластеру \\
\hline $\begin{array}{l}\text { курортно- } \\
\text { лікувального } \\
\text { туризму }\end{array}$ & $\begin{array}{l}\text { дитячі заклади } \\
\text { оздоровлення } \\
\text { санаторного типу }\end{array}$ & $\begin{array}{l}\text { розміщення впродовж кліматолікувальної, грязелікувальної, } \\
\text { бальнеологічної оздоровчої зміни, лікувально-оздоровчі } \\
\text { прогулянки, харчування, транспортні перевезення спеціального } \\
\text { призначення та/або інших видів транспорту, страхування. }\end{array}$ \\
\hline $\begin{array}{l}\text { оздоровчого- } \\
\text { рекреаційного } \\
\text { туризму }\end{array}$ & $\begin{array}{l}\text { дитячі центри, } \\
\text { позаміські заклади } \\
\text { оздоровлення та } \\
\text { відпочинку }\end{array}$ & $\begin{array}{l}\text { розміщення протягом оздоровчоїтавідпочинкової(ут.ч. тематичної, } \\
\text { профільної) зміни, харчування, транспортні перевезення } \\
\text { спеціального призначення та/або інших видів транспорту, } \\
\text { страхування, тематичні прогулянки, екскурсії, відвідування } \\
\text { аквапарків, дельфінаріїв, зоопарків. }\end{array}$ \\
\hline $\begin{array}{c}\text { рекреачійного } \\
\text { туризму }\end{array}$ & $\begin{array}{c}\text { дитячі заклади } \\
\text { відпочинку }\end{array}$ & $\begin{array}{l}\text { розміщення впродовж відпочинкової (ут.ч. тематичної, профільної) } \\
\text { зміни, харчування, транспортні перевезення спеціального } \\
\text { призначення та/або інших видів транспорту, страхування, } \\
\text { тематичні прогулянки, екскурсії, відвідування музеїв, аквапарків, } \\
\text { дельфінаріїв, зоопарків. }\end{array}$ \\
\hline $\begin{array}{l}\text { культурно- } \\
\text { пізнавального } \\
\text { (икільного) } \\
\text { туризму та } \\
\text { рекреації }\end{array}$ & $\begin{array}{l}\text { туроператори, } \\
\text { турагенції, } \\
\text { екскурсійні бюро }\end{array}$ & $\begin{array}{l}\text { тематичні екскурсії, подорожі, тимчасове перебування в } \\
\text { колективних засобах розміщення відповідного типу, харчування, } \\
\text { страхування, перевезення на транспорті спеціального призначення } \\
\text { та/або інших видів транспорту, відвідування музеїв, аквапарків, } \\
\text { дельфінаріїв, зоопарків, парків розваг. }\end{array}$ \\
\hline $\begin{array}{c}\text { розважального } \\
\text { туризму }\end{array}$ & $\begin{array}{c}\text { туроператори, } \\
\text { турагенції }\end{array}$ & $\begin{array}{l}\text { подорожі з метою відвідування концертів, фестивалів, тематичних } \\
\text { змагань, тимчасове перебування в колективних засобах розміщення } \\
\text { відповідного типу, харчування, страхування, перевезення на } \\
\text { транспорті спеціалізованого призначення та/або інших видів } \\
\text { транспорту, відвідування аквапарків, дельфінаріїв, парків розваг, } \\
\text { зоопарків. }\end{array}$ \\
\hline $\begin{array}{l}\text { спортивного } \\
\text { туризму та } \\
\text { рекреачї }\end{array}$ & $\begin{array}{c}\text { дитячо-юнацькі } \\
\text { спортивні школи, } \\
\text { центри туризму } \\
\text { і краєзнавства } \\
\text { учнівської молоді } \\
\text { (станції юних } \\
\text { туристів) }\end{array}$ & $\begin{array}{l}\text { туристсько-спортивні походи, зльоти, естафети та змагання, } \\
\text { тимчасове перебування в колективних засобах розміщення } \\
\text { відповідного типу (за потреби), харчування, страхуванн, } \\
\text { перевезення на транспорті спеціалізованого призначення та/або } \\
\text { інших видів транспорту. }\end{array}$ \\
\hline $\begin{array}{l}\text { навчально- } \\
\text { краєзнавчого } \\
\text { туризму та } \\
\text { рекреації }\end{array}$ & $\begin{array}{l}\text { центри туризму } \\
\text { і краєзнавства } \\
\text { учнівської молоді } \\
\text { (станції юних } \\
\text { туристів) }\end{array}$ & $\begin{array}{l}\text { тематичні екскурсії, подорожі для участі в тематичних конкурсах, } \\
\text { акціях, конференціях, експедиції, тимчасове перебування } \\
\text { в колективних засобах розміщення відповідного типу (за } \\
\text { потреби), харчування, страхування, перевезення на транспорті } \\
\text { спеціалізованого призначення та/або інших видів транспорту, } \\
\text { відвідування музеїв, зоопарків. }\end{array}$ \\
\hline $\begin{array}{l}\text { патріотичного } \\
\text { туризму та } \\
\text { рекреації }\end{array}$ & $\begin{array}{l}\text { центрами туризму } \\
\text { і краєзнавства } \\
\text { учнівської молоді } \\
\text { (станції юних } \\
\text { туристів) }\end{array}$ & $\begin{array}{l}\text { тематичні екскурсії, подорожі для участі в тематичних конкурсах, } \\
\text { акціях, конференціях, експедиції, тимчасове перебування } \\
\text { в колективних засобах розміщення відповідного типу (за } \\
\text { потреби), харчування, страхування, перевезення на транспорті } \\
\text { спеціалізованого призначення та/або інших видів транспорту. }\end{array}$ \\
\hline $\begin{array}{l}\text { виїзного } \\
\text { курортно- } \\
\text { оздоровчого } \\
\text { туризму }\end{array}$ & $\begin{array}{c}\text { туроператори, } \\
\text { турагенції }\end{array}$ & $\begin{array}{l}\text { подорож до закордонної дестинації лікувально-оздоровчої } \\
\text { спеціалізації, тимчасове розміщення в спеціалізованих дитячих } \\
\text { таборах, харчування, перевезення на транспорті спеціалізованого } \\
\text { призначення та/або інших видів транспорту, страхування, розваги. }\end{array}$ \\
\hline $\begin{array}{c}\text { виїзного } \\
\text { навчально- } \\
\text { рекреаційного } \\
\text { туризму }\end{array}$ & $\begin{array}{c}\text { туроператори, } \\
\text { турагенції }\end{array}$ & $\begin{array}{l}\text { подорож до закордонної дестинації рекреаційної спеціалізації за } \\
\text { кордономз метою набуття деяких знань, навичокта вмінь, тимчасове } \\
\text { розміщення в спеціалізованих дитячих таборах, харчування, } \\
\text { перевезення на транспорті спеціалізованого призначення та/або } \\
\text { інших видів транспорту, страхування, розваги. }\end{array}$ \\
\hline
\end{tabular}

Складено за матеріалами [3-6; 8] 
манітних рекреаційних галузей; 2) розвиток комплексоформуючої галузі спеціалізації та групування рекреаційних підприємств за галузевими та територіальними ознаками; 3) формування територіальної структури [7, с. 8].

Також Котляров Є.В. визначає таксономічну систему територіальних рекреаційних комплексів (ТРК), які взаємопов'язані між собою. Так, до складу ТРК країни входять одиниці першого, другого та третього порядку, відповідно, районні ТРК, рекреаційні мікрорайони, рекреаційні підприємства [7, с. 9].

На нашу думку, з огляду на те, що дитячий туризм та рекреація - одна 3 форм туристськорекреаційної діяльності людини, доцільно розглядати територіальний комплекс дитячого туризму та рекреації як форму геопросторової організації, а також визначати його як об'єкт суспільно-географічних досліджень.

Александрова О.Ю наголошує на тому, що в науковій літературі все частіше розглядають поняття «кластеру» як особливої форми геопросторової організації виробництва в умовах ринкової економіки [1]. Так, для дослідження територіального комплексу дитячого туризму та рекреації доцільно використати «кластерний підхід», який вперше було запропоновано М. Портером.

Кластер - це група географічно локалізованих підприємств, фірм та пов'язаних 3 ними організацій, які діють в певній сфері, а також характеризуються спільною діяльністю та взаємодоповнюють одна одну [10, с. 258].

Таким чином, кластер дитячого туризму та рекреації - це група географічно локалізованих підприємств, організацій, установ, які надають, контролюють або координують надання туристськорекреаційних та супутніх послуг дітям шкільного віку, використовуючи суспільно-географічний потенціал відповідної території. Територіальний комплекс дитячого туризму та рекреації - це міжгалузевий кластер високого рівня організації.

Відповідно до теорії конкурентних переваг М. Портера, кластери можуть охоплювати територію від одного міста або регіону (області, штату) до країни, а іноді декілька сусідніх держав [10, с. 258]. Руднева М.Г. за ознакою територіального поділу виділяє промисловий (локальний), регіональний, міжрегіональний, міжнародний, транскордонний кластери [12, с. 77-78]. Тим самим, кластери, які включає комплекс дитячого туризму та рекреації можуть формуватися на різних територіальних рівнях.
3 урахуванням сформованих видів дитячого туризму та рекреації в Україні, на основі концепції Топчієва О.Г. про рекреаційні комплекси $[15$, с. $563-$ 565], а також використовуючи кластерний підхід, нами запропоновано кластерну модель комплексу дитячого туризму та рекреації в Україні, яка відображена на рис.1.

В основі виділення кластерів лежить групування за функціональною ознакою географічно локалізованих підприємств, які надають однакові туристсько-рекреаційні та супутні послуги для задоволення дитячих потреб у відпочинку, оздоровленні, пізнанні або навчанні тощо, де сукупність таких послуг складає туристичний продукт певної території (див. табл.1).

Висновки. Отже, використовуючи кластерний підхід було визначено, що територіальний комплекс дитячого туризму та рекреації - це міжгалузевий кластер високого рівня організації. Кластер дитячого туризму та рекреації - це група географічно локалізованих підприємств, організацій, установ, які надають, контролюють або координують надання туристсько-рекреаційних та супутніх послуг дітям шкільного віку, використовуючи суспільно-географічний потенціал відповідної території. Запропонована кластерна модель територіального комплексу дитячого туризму та рекреації на локальному рівні охоплює наступні елементи (кластери): 1) курортнолікувального туризму, 2) оздоровчо-рекреаційного туризму, 3) рекреаційного туризму, 4) культурнопізнавального (шкільного) туризму та рекреації, 5) розважального туризму, 6) спортивного туризму та рекреації, 7) навчально-краєзнавчого туризму та рекреації, 8) патріотичного туризму та рекреації, 9)виїзного курортно-оздоровчого туризму, 10) виїзного рекреаційно-навчального туризму. На державному та регіональному рівнях сукупність вищезазначених кластерів формує: 1) кластер курортно-оздоровчого туризму та рекреації, 2) кластер пізнавально-розважального туризму та рекреації, 3) кластер спортивно-краєзнавчого туризму та рекреації, 4) кластер оздоровчорекреаційно-навчального туризму.

Питання територіального комплексу дитячого туризму та рекреації заслуговує на подальше поглиблене суспільно-географічне дослідження, яке, в першу чергу, буде стосуватися визначення компонентної та територіальної структур такого комплексу, встановлення основних відношень між його елементами тощо.

\section{References:}

1. Aleksandrova A. Yu. Turistskie klasteryi: soderzhanie, granitsyi, mehanizm funktsionirovaniya [Tourists' clusters: content, boundaries, mechanism of functioning]: [Electronic resource]. Sovremennyie problemyi servisa i turizma [Modern problems of Service and Tourism], 2007, \# 1, pp. 51-61. Access mode: http://tourlib.net/statti_ tourism/aleksandrova3.htm (In Russian).

2. Beidyk O.O. Ukrainsko-rosiiskyi slovnyk terminiv $i$ poniat z heohrafii turyzmu $i$ rekreatsiinoi heohrafii [Ukrainian-Russian dictionary of terms and concepts on Geography of Tourism and Geography of Recreation]: 
[Electronic resource]. Kyiv, «Kyevskyi un-t», 1997, 305 p. Access mode: http://www.geograf.com.ua/glossary/terminiz-galuzi-turizmu-ta-rekreatsiji/teritorialno-rekreatsijnij-kompleks-trk (In Ukrainian).

3. Derzhavna sluzhba statystyky [State Statistics Service]: [Electronic resource]. Access mode: http://www.ukrstat. gov.ua/ (In Ukrainian).

4. Informatsiynyy dovidnyk pro stan rozvytku dytyacho-yunats'koho turyzmu i krayeznavstva $v$ Ukrayini [Informational handbook about the development of children's tourism and regional studies in Ukraine]. Kyiv, Ukrayins'kyy derzhavnyy tsentr turyzmu i krayeznavstva uchnivs'koyi molodi, 2014, 27 p. (In Ukrainian).

5. Kilins'ka K., Rudenko V., Anipko N., Andrusyak N., Konovalova N. ta in. Teoretychni ta prykladni aspekty rekreatsiynoho pryrodokorystuvannya $v$ Ukrayini: monohrafiya [Theoretical and practical aspects of recreational nature management in Ukraine]. Chernivtsi, Chernivets'kyy natsional'nyy universytet imeni Yuriya Fed'kovycha, 2010, 250 p. (In Ukrainian).

6. Kolotukha O.V. Dytyacho-yunats'kyy turyzm v Ukrayini yak terytorial'na sotsial'no-ekonomichna systema: problemy ta perspektyvy rozvytku [Children's tourism in Ukraine as a territorial social and economic system: problems and prospects of development]. Abstract of PhD Tesis. Kyiv, 2005, 20 p. (In Ukrainian).

7. Kotlyarov E.A. Geografiya otdyiha i turizma: Formirovanie $i$ razvitie territorialnyih rekreatsionnyih kompleksov [Geography of leisure and tourism: Formation and development of territorial recreational complexes]. Moscow, Mysl, 1978, 238 p. (In Russian).

8. Malynovs'ka O. Heohrafiya dytyachoho turyzmu. [Geography of children's tourism]. Krayeznavstvo. Heohrafiya. Turyzm. [Regional Studies. Geography. Tourism]. Kyiv, 2008, \# 44, pp. 3-5. (In Ukrainian).

9. Pistun M.D. Osnovy teorii suspilnoi heohrafi [Fundamentals of Human Geography Theory]. Kyiv, Vyshcha shkola, 1996, 231 p. (In Ukrainian).

10. Porter M. Konkurentsiya [Competition]. Moscow, Publishing House of «Vilyams», 2005, 608 p. (In Russian).

11. Pushkar B. T., Pushkar Z. M. Terytorial'na orhanizatsiya rekreatsiynoho hospodarstva rehionu [Territorial organization of regional recreation]. Ternopil', Vektor, 2014, 196 p. (In Ukrainian).

12. Rudneva M. H. Klastery yak ob'iekt vyvchennia krainoznavstva [Clusters as the object of country studies research]. Heohrafia ta turyzm [Geography and Tourism]. Kyiv, 2010, \# 6, pp. $76-79$ (In Ukrainian).

13. Shablii O.I. Osnovy zahalnoi supilnoi heohrafii [Fundamentals of general human geograhpy]. Lviv, Ivan Franko Lviv National University, 2003, 444 p. (In Ukrainian).

14. Stafiichuk V. I. Rekrealohiia [Recreation]. Kyiv, Alterpres, 2006, 264 p. (In Ukrainian)

15. Topchiiev O.H. Suspilno-heohrafichni doslidzhennia: metodolohiia, metody, metodyka [Human geography research: methodology and techniques]. Odesa, Astroprynt, 2005, 631 p. (In Ukrainian). 